\title{
Morphological and molecular diagnosis of Hypoderma spp. in Mosul city, Iraq
}

\author{
D.G. Alhamdani ${ }^{(i)}$ and N.S. Alhayali \\ Department of Microbiology, College of Veterinary Medicine, University of Mosul, Mosul, Iraq
}

\begin{tabular}{l} 
Article information \\
\hline Article history: \\
Received April 17, 2021 \\
Accepted June 19, 2021 \\
Available online December 20, 2021 \\
\hline Keywords: \\
Cattle \\
PCR-RFLP \\
Warble \\
Hypoderma bovis \\
Hypoderma lineatum \\
\hline Correspondence: \\
N.S. Alhayali \\
nadias.alhayali@gmail.com
\end{tabular}

\begin{abstract}
Hypodermosis is a distinctive ectoparasitic disease infesting cattle; Hypoderma bovis and Hypoderma lineatum are the most common causes of this myasis. In this study 78 larvae were collected from infected cattle by extraction in the Educational Veterinary Hospital, from Kokjali and Bazwaya flocks and from the skin of slaughtered in Mosul abattoirs for the period from October 2020 to March 2021. Morphological identification by using stereomicroscope depending on patterns of spinulation of the $10^{\text {th }}$ abdominal segment and peritremes structure of L3 classified as H. bovis and H. lineatum. Molecular technique by traditional PCR applied on $16 \mathrm{~L} 3$ of the genus Hypoderma revealed that the reaction product was $500 \mathrm{bp}$ by amplification of $\mathrm{mt} \mathrm{CO} 1$ gene while the results of PCRRFLP using restriction TaqI enzyme for differentiation between the two species indicated reaction products $300 \mathrm{bp}$ for $H$. bovis and $200 \mathrm{bp}$ for $H$. lineatum respectively. The results of molecular analysis by PCR and PCR-RFLP proved the existence of these two species of Hypoderma in Mosul.
\end{abstract}

DOI: 10.33899/ijvs.2021.129942.1704, (CAuthors, 2022, College of Veterinary Medicine, University of Mosul.

This is an open access article under the CC BY 4.0 license (http://creativecommons.org/licenses/by/4.0/).

\section{Introduction}

Cattle are exposed to different ecto-parasites as ticks (1) and endo-parasites as blood protozoa (2), tissue protozoa such as Neospora caninum and Toxoplasma gondii $(3,4)$ infections. One of the most common ectoparasitic infestation is cattle grub also known as cattle hypodermosis resulted from larvae of $H$. bovis, and $H$. lineatum (5).

The warble fly infestation (WFI) or Hypodermosis, causes warbles in the subcutaneous of infested animals which considered the distinctive feature for this disease, this myasis is present worldwide and has negative effects on cattle production $(5,6)$.

$H$. bovis and $H$. lineatum mainly affect bovine, horses and human (7). The discrimination morphologically between the two species $H$. bovis and $H$. lineatum based on peritreme structure and on the order of spinulation located on the tenth segment of larvae $3(8,9)$.

Recently, the cytochrome oxidase subunit 1 gene of the mitochondrial DNA (CO1-mtDNA) considered as the best gene used in molecular detection and molecular phylogenetic analysis (5). Furthermore, molecular analysis by this gene is ideal for identifying 5 species of Hypoderma: $H$. bovis, $H$. lineatum, H. diana, $H$. tarandi, and $H$. actaeon (10).

Hypoderma spp. in Pakistan and Turkey were identified through CO1 mtDNA sequence analysis and PCR-RFLP $(11,12)$.

It is essential for accurate identification between $H$. bovis and $H$. lineatum for proper treatment of the infested cattle, the discrimination of $H$. bovis from $H$. lineatum is significant because complications could occur during the use of drugs during migration of L1 which cause paralysis with $H$. bovis while esophagitis occur with $H$. lineatum (13).

The aim of this research is essentially using morphological and molecular differentiation between Hypoderma spp. in naturally infested bovine in Mosul city by morphological features and PCR-RFLP technique of gene $\mathrm{CO} 1$. 


\section{Materials and methods}

\section{Larvae collection}

From October 2020 to March 2021, Hypoderma spp. Larvae 3 (L3) samples were collected by extraction from the back of naturally infested cattle coming to the Veterinary Hospital, from different flocks and from the skin of slaughtered cattle in Mosul city. The samples were washed in phosphate saline buffer several times and identified depending on morphological description such as shape, color, size and spinulation of the tenth segment as well as morphology of L3 spiracular plates under steromicroscope $(8-10,14)$ and then were preserved in ethanol $70 \%$ for PCR analysis.

\section{Extraction of DNA}

DNA extraction done using tissue kit type Geneaid UKAS after drying the samples from 16 L3 of Hypoderma spp. following the manufacturer's instructions. Measuring the concentration and purification of DNA using biodrop instrument in the molecular laboratory of the Department of Biology, College of Sciences, Mosul University; by adding $1 \mu 1$ of DNA extracted from larvae samples and loaded into wells $A_{260} \mathrm{~nm} / \mathrm{A}_{280} \mathrm{~nm}$, DNA concentrations of all samples ranged between $50-150 \mathrm{ng} / \mu 1$ and purification between 1.4 -1.7. Electrophoresis is processed on DNA samples extracted from larvae in $1 \%$ of agarose gel (Jena Bioscience, Germany).

\section{Polymerase Chain Reaction (PCR)}

Concentration of all DNA extracted was controlled by diluting TE buffer to obtain the required concentration and it was $25 \mathrm{ng} / \mu 1$ according to the following equation $\mathrm{C} 1 \mathrm{XV} 1=\mathrm{C} 2 \mathrm{~V} 2$. The region of (COX1-mtDNA) amplified by using primer as used by (12) and then prepared the primer used in the PCR reaction supplied by Alpha DNA Montreal, Quebec H3C 0J7 as shown on (Table 1). Prepared DNA Master Reaction mixture. DNA reaction mixture was prepared according to the following (Table 2).

The negative control PCR sample contains all mixtures except DNA extracted from larvae samples. All tubes were centrifuged using microfuge with high speed 3-5 seconds to complete contents reaction mixture. Tube samples should be refrigerated during procedures. Reaction sample tubes were loaded into the thermocycler to perform the amplification reaction using the special program for each reaction as shown on (Table 3 ).

After the end of the reaction, $5 \mu 1$ samples of each PCR tubes were loaded in the agarose wells $1 \%$ adding Ladder DNA (Biolaps) in one of the wells. Then samples were moved to electrophoresis with 50 volts $60-70 \mathrm{~min}$. The get was put in the ultraviolet instrument to see the dyed bands and to notice the amplification bands then photographed by a digital camera. Base pairs sizes were estimated according to bands locations by comparing them with DNA Ladder.
Table 1: Primer of Alpha DNA (12)

\begin{tabular}{lcc}
\hline Primer & Primer sequences ( 5'-3') & bp \\
\hline Hyp F & TACAGTTGGAATAGACGTTGATAC & \multirow{2}{*}{500} \\
Hyp R & TCCAATGCACTAATCTGCCATATTA & \\
\hline
\end{tabular}

Table 2: DNA reaction mixture

\begin{tabular}{lc}
\hline Contents & Total size $(\mu \mathrm{l})$ \\
\hline Master Mix 2X & 10 \\
DNA Template & 4 \\
Forward Primer & 1 \\
Reverse Primer & 1 \\
Distal water (deionized) & 4 \\
\hline
\end{tabular}

Table 3: Cycling conditions of PCR for amplification of Hypoderma spp

\begin{tabular}{llccc}
\hline $\mathrm{N}$ & Stage & ${ }^{\circ} \mathrm{C}$ & Time $(\mathrm{m})$ & $\mathrm{n}$ cycle \\
\hline 1 & initial denaturation & 95 & 5 & 1 \\
2 & denaturation & 95 & 0.45 & \\
3 & annealing & 60 & 1.30 & 40 \\
4 & extension & 72 & 2 & \\
5 & final extension & 72 & 7 & 1 \\
6 & cooling & 4 & 4 & 1 \\
\hline
\end{tabular}

\section{PCR-RFLP technique}

$5 \mu \mathrm{l}$ PCR product is taken and added to it $0.5 \mu \mathrm{l}$ of Restriction endonuclease enzyme Taq I the incubated at $37^{\circ} \mathrm{C}$ for $3 \mathrm{~h}$, then separated the restriction fragments agarose gel $1 \%$, finally stained by red safe and photographed.

\section{Results}

Third larvae of genus Hypoderma were classified morphologically by microscopic examination using stereomicroscope, identified L3 $\mathrm{H}$. lineatum and L3 $\mathrm{H}$. bovis (Table 4; Figure 1) show the presence or absence of dorsal spines on $10^{\text {th }}$ abdominal segment as a distinctive feature in differentiating between the two species (Figure 2) illustrates the absence of dorsal spines in the $10^{\text {th }}$ abdominal segment of $H$. bovis. The structure of the posterior peritreme in $H$. bovis is longer and narrower than $H$. lineatum which is considered another distinctive and reliable feature in distinguishing between the two species (Figures 3). The molecular discrimination using PCR technique by amplification of mt-CO1 gene of 16 larvae 3 of the genus Hypoderma revealed that the reaction product was $500 \mathrm{bp}$ (Figure 4) whereas the results of molecular analyses using PCR-RFLP revealed $200 \mathrm{bp}$ and $300 \mathrm{pb}$, bands of RFLP profile revealed 1,3,4,7 of $\mathrm{H}$. lineatum and 2,5,8 of H. bovis respectively (Figure 5). 
Table 4: Distinctive features of $10^{\text {th }}$ of abdominal segment of L3of Hypoderma species

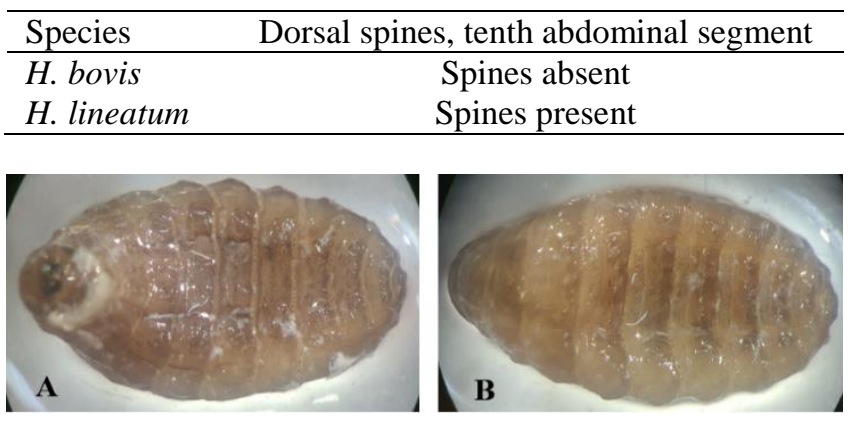

Figure 1: Larvae 3 of $H$. bovis (A. ventral, B. dorsal). 2.5x.
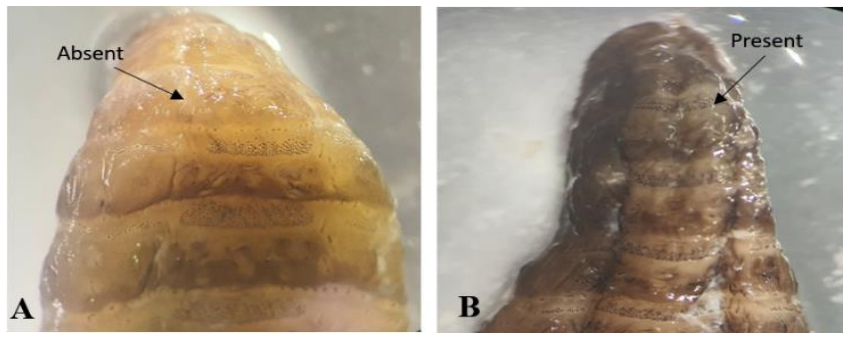

Figure 2: A- absence or B-Presence of dorsal spines in the $10^{\text {th }}$ abdominal segment of $H$. bovis. $2.5 \mathrm{x}$.
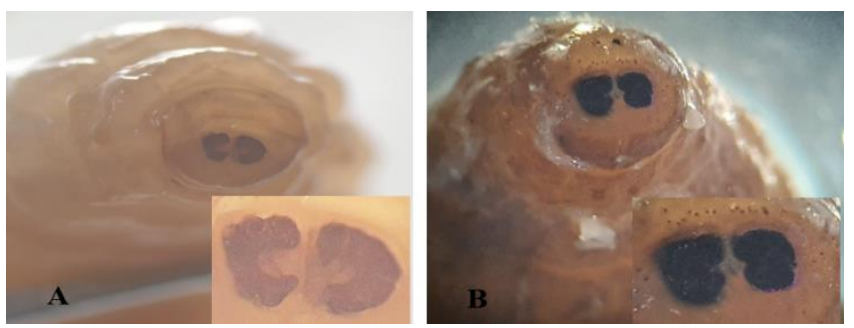

Figure 3: posterior peritreme (a. Hypoderma bovis, b. Hypoderma lineatum). 10x.

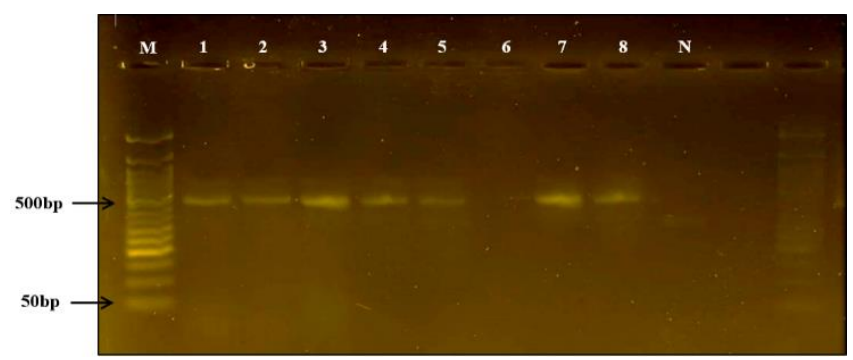

Figure 4: PCR Electrophoresis, CO1 mtDNA amplification carried out using specific primer: M: DNA marker 50bp 1, 2, 3, 4, 5, 7, 8 samples of L3 of Hypoderma spp. Positive 500bp, sample 6 Negative. $\mathrm{N}$ represents negative control.

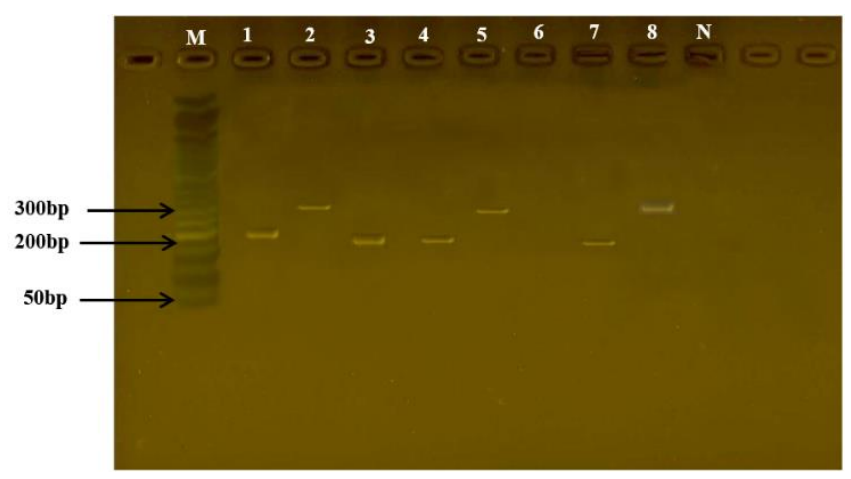

Figure 5: PCR-RFLP product digested with TaqI enzyme. M: DNA marker 50bp. 1,3,4,7 (200bp) H. lineatum, 2,5,8 (300bp) H. bovis.

\section{Discussion}

The most important species cause hypodermosis in cattle are $H$. bovis, and $H$. lineatum (15). In this study morphological and molecular methods were applied to identify L3 Hypoderma species. Our results revealed that morphological identification L3 of both species is considered difficult because of debris and remains of the host cell, blood and puss covering and attaching the larvae make it difficult to recognize the spinulation pattern of the $10^{\text {th }}$ abdominal segment even with ethanol preservation; furthermore, extraction of L3 could damage the peritremes which is also another important feature this was in conformity with Balkaya et al., (11) who also added more reasons including: Hypoderma spp. share the same host on the back of infested cattle, variation between larvae samples collected from hosts and countries, the absence of recent unified morphological keys and finally dark or brown chitinous color of L3 make it uneasy to diagnose peritremes shapes which is considered as a distinctive feature for identification between species.

Since it was not reliable to identify morphologically between $H$. bovis, and $H$. lineatum, so current study highlighted usefulness and significance of molecular technique for accurate discrimination and confirmation between the two species in cattle especially when similar species parasitize in the same host and also considered a good tool for the study of the biology of the myasis specially in immature stages $(5,11,16,17)$. The molecular identification by the PCR-RFLP and nucleotides sequences of the most variable region of gene $\mathrm{CO} 1 \mathrm{mtDNA}$ presented important data in the identification of Hypoderma species in China (17) in East Turkey (11) and in Portugal $(18,19)$. and also used as goal gene in several molecular and phylogenetic researches for L3 (20).

The results of PCR-RFLP assay in this study by TaqI restriction enzyme allowed to differentiate between the species by $\mathrm{CO} 1$ amplicons and that the size of amplification 
of bands is $200 \mathrm{bp}$ of $H$. lineatum while $300 \mathrm{bp}$ for $H$. bovis. The Taq1 restriction enzyme is used to discriminate between $H$. bovis and $H$. lineatum on 438, and $250 \mathrm{bp}$ bands for $H$. bovis and 488 and $200 \mathrm{bp}$ for H. lineatum (17) and used BfaI and HinfI enzymes couldn't digest $H$. bovis and $H$. lineatum. The aim of differentiation between Hypoderma species is essential to accurately treat infected animals on proper time; furthermore, these species have different migrating patterns thus it is a major threat in drug administration when $\mathrm{L} 1$ of $H$. bovis presence causes paralysis in the hindquarter and L1 of $H$. lineatum causes blot the esophagus $(21,22)$

\section{Conclusion}

This study concluded the morphological and molecular identification of Hypoderma bovis and Hypoderma lineatum depending on morphological characterization of L3 and by PCR-RFLP to confirm the existence of both species in Iraq, Mosul. The results of this research revealed that morphological differentiation is not sufficient for differentiation and difficult due to the fact that L3 of both species share the same host and localities in the back of the infested cattle. Using molecular analysis proved the existence of both species and it is very important in treatment because of the different migration patterns of L1 of both species.

\section{Acknowledgement}

The researchers would like to express their sincere gratitude to the Dean of College of Veterinary Medicine, University of Mosul and to staff of Department of Microbiology for their efforts and support to complete this research.

\section{Conflict of interests}

Researchers declare that they have no conflicts in interest regarding the publication of this research.

\section{References}

1. Ismael SS, Omer LT. Molecular identification of new circulating Hyalomma asiaticum asiaticum from sheep and goats in Duhok governorate, Iraq. Iraqi J Vet Sci. 2021;35(1):79-83. DOI: 10.33899/ijvs.2020.126330.1298

2. Alfatlawi MA, Jasim AA, Jarad NE, Khlaif SF. Clinical and molecular identification of ruling Theileria annulata strains in cattle calves in Al-Diwaniyah province, Iraq. Iraqi J Vet Sci. 2021;35(1):115-119. DOI: 10.33899/ijvs.2020.126429.1319

3. Nooruldeen MY, Jaafar SE, Salih AI. Seroprevalence of Neospora caninum infections in cattle in Kirkuk province. Iraqi J Vet Sci. 2021;35 (2): 331-334. DOI: 10.33899/ijvs.2020.126832.1394

4. Shaapan1 RM, Toaleb NI, Abdel-Rahman EH. Detection of Toxoplasma gondii-specific immunoglobulin (IgG) antibodies in meat juice of beef. Iraqi $\mathbf{J}$ Vet Sci. 2021;35(2):319-324. DOI: 10.33899/ijvs.2020.126829.1390

5. Ahmed H, Simsek S, Zaki CE, Kesik HK and Kilinc SG. Molecular characterization of Hypoderma spp. in domestic ruminants from Turkey and Pakistan. J Parasitol. 2017;103(4):303-308. DOI: 10.1645/16-185

6. Boulard C. Durably controlling bovine hypodermosis. Vet Res 2002;33:455-464. DOI: 10.1051/vetres:200203

7. Boulard C, Alvinerie M, Argente G, Languille J, Paget L, Petit E. A successful, sustainable and low-cost control programme for bovine hypodermosis in France. Vet Parasitol. 2008;158:1-10. DOI: 10.1016/j.vetpar.2008.07.026

8. James MT. the flies that cause myiasis in man. Washington: US. Government Printing Office; 1947. 106-112 p. 10.5962/bhl.title.65688

9. Zumpt F. Myiasis in man and animals in the old world, a textbook for physicians, veterinarians, and zoologists. London: Butterworth \& Co.; 1965. 218-224 p.

10. Otranto D, Traversa D, Tarsitano E, Stevens J. Molecular differentiation of Hypoderma bovis and Hypoderma lineatum (Diptera: Oestridae) by polymerase chain reaction-restriction fragment length polymorphism (PCR-RFLP). Vet Parasitol. 2003;10:197-201. DOI: $10.1016 / \mathrm{s} 0304-4017(02) 00418-1$

11. Balkaya I, Simsek S, Saki CE. A serological and molecular survey of cattle hypodermosis in east-Turkey. Vet Parasitol. 2010;173:287-291. DOI: 10.1016/j.vetpar.2010.07.009

12. Hasan MU, Khan MN, Weigl S, Iqbal MF, Abubakar M, Zafar MA, Iqbal Z. Molecular detection and differentiation of Hypoderma species (Diptera: Oestridae) affectin cattle in Pakistan. Pakistan J Zool. 2015;47(4):1009-1014. [available at]

13. Losson B, Lonneaux JF, Liebisch A. Chemoprophylaxis and chemotherapy of cattle hypodermosis. In: Boulard C, Pithan D, O'Brian D, Webster K, Sampimon OC, editors. Improvement in the control methods for warble fly in livestock. Luxembourg: Nilssen Press; 1998. 62-67 p. [available at]

14. Otranto D, Traversa D, Giangaspero A. Myiasis caused by Oe.stridae: serological and molecular diagnosis. Parasitol. 2004;46:169-172. [available at]

15. Otranto D, Colwell DD, Traversa D, Stevens JR. Species identification of Hypoderma affecting domestic and wild ruminants by morphological and molecular characterization. Med Vet Entomol. 2003;17:316-325 DOI: 10.1046/j.1365-2915.2003.00446.x

16. Hassan MU, Khan MN, Abubakar M, Waheed HM, Iqbal Z, Hussain M. Bovine hypodermosis-a global aspect. Trop Anim Hlth Prod. 2010;42(8):1615-1625. DOI: $10.1007 / \mathrm{s} 11250-010-9634-\mathrm{y}$

17. Otranto D, Traversa D, Colwell DD, Guan G, Giangaspero A, Boulard C, Yin H. A third species of Hypoderma (Diptera: Oestridae) affecting cattle and yaks in China: molecular and morphological evidence. $\mathbf{J}$ Parasitol. 2004;90:958-65. DOI: 10.1645/GE-232R

18. Otrantoa D, Tarsitanoa E, Giangasperob A, Puccini V. Differentiation by polymerase chain reaction-restriction fragment length polymorphism of some Oestridae larvae causing myiasis. Vet Parasitol. 2000;90:305-313. DOI: 10.1016/S0304-4017(00)00257-0

19. Ahmed H, Sousa S, Simsek S, Anastácio S, Kilinc S. First molecular characterization of Hypoderma actaeon in cattle and red deer (Cervus elaphus) in Portugal. Korean J Parasitol. 2017;55(6):653-658. DOI: 10.3347/kjp.2017.55.6.653

20. Lunt DH, Zhang DX, Szymura JM, Hewitt GM. The insect cytochrome oxidase I gene: Evolutionary patterns and conserved primers for phylogenetic studies. Insect Mol Biol 1996;5:153-165. DOI: 10.1111/j.1365-2583.1996.tb00049.x

21. Ahmed H, Afzal MS, Mobeen M, Simsek S. An overview on different aspects of hypodermosis: Current status and future prospects. Acta Tropica. 2016;162: 35-45. DOI: 10.1016/j.actatropica.2016.05.016

22. Khan M, Iqbal Z, Sajid M, Anwar M, Needham G, Hassan M. Bovine hypodermosis: prevalence and economic significance in southern Punjab, Pakistan. Vet Parasitol. 2006;141:386-390. DOI: $\underline{\text { 10.1016/j.vetpar.2006.05.014 }}$ 
يرقات من الحيوانات المصابة بطريقة استخراجها من التورمات

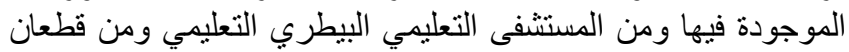

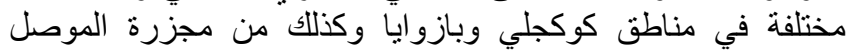

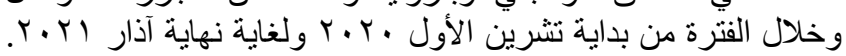

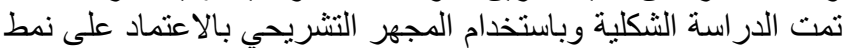

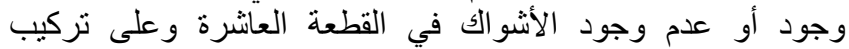

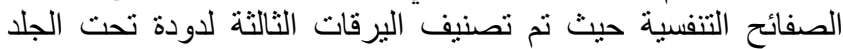

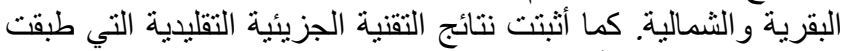

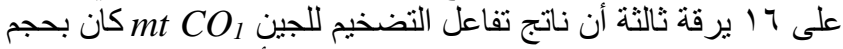

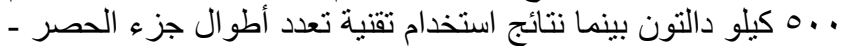

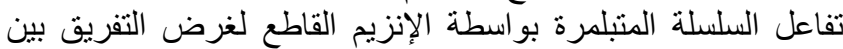

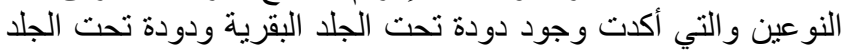

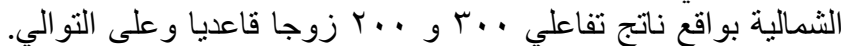
أثنتت نتائج الدراسة باستخدام التقنية الجزيئية وجود نواعي نواعي دودة تحت

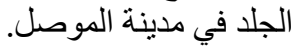

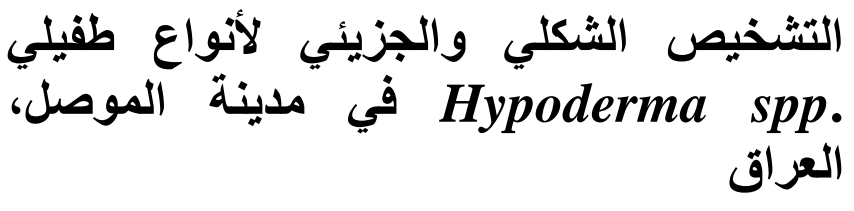

دعاء غاتم الحمداني و نادية سلطان الحيالي

فرع الأحياء المجهرية، كلية الطب البيطري، جامعة الموصل،

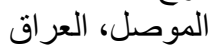

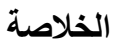

داء النغف الجلدي هو من الأمر اض الطفيلية الخارجية التي تخمج

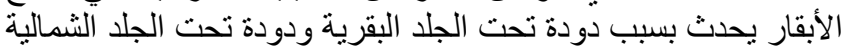

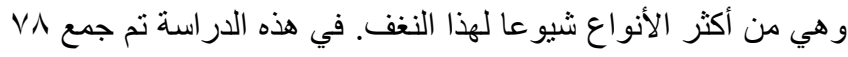

